\title{
THE EFFECTIVENESS OF COOPERATIVE LEARNING MODEL NUMBERED HEADS TOGETHER (NHT) TYPE AND TALKING STICK TYPE OF STUDENTS IN SMP NEGERI 3 SENTOLO
}

\author{
Dwi Sholikhatun $^{a}$, Edi Prajitno ${ }^{b}$ \\ Program Studi Pendidikan Matematika Universitas Ahmad Dahlan \\ Jalan Ring Road Selatan, Tamanan, Banguntapan, Bantul Yogyakarta \\ a Sholikhadwi@gmail.com, ${ }^{\mathrm{b}}$ Ediprajitno@yahoo.com
}

\begin{abstract}
In SMP Negeri 3 Sentolo, the learning activities tend to teacher learning-centered, it causes boredom and tiring of students. This can affect student learning results. One can be applied to solve this problem as an alternative learning model is a cooperative learning model NHT type and Talking Stick type. Therefore the purpose of this study is to determine the effectiveness of cooperative learning model NHT type and Talking Stick type of VII students in SMP Negeri 3 Sentolo Kulonprogo on even semester in the academic year of 2015/2016. The population in this study were all students of class VII SMP Negeri 3 Sentolo Kulonprogo academic year 2015/2016. That is consisting of six classes with 168 students. The samples were taken two classes used random technique sampling for each class. It is obtained VII A as the experimental class I and VII C as the experimental class II. The data analysis technique used a prerequisite test. It includes a normalized test, homogeneity test, and hypothesis test of two parties and one party. Based on the calculation of the two parties hypothesis test with significance level a $=5 \%$ and 56 degrees of freedom obtained value $t_{c a l}=-1,4079$ and $t_{\text {table }}=2,0045$ so $t_{c a l}<t_{\text {table }}$, then accepted $\mathrm{H}_{0}$ means there is no difference in the students' mathematics learning result which uses cooperative learning model NHT type and Talking stick type. On the other hand, for one party hypothesis test with significance level $\mathrm{a}=5 \%$ and 56 degrees of freedom is obtained $t_{c a l}=-1,4079$ and $t_{\text {table }}=$ 1,6733 so $t_{c a l}<t_{\text {table }}$, then accepted $\mathrm{H}_{0}$ it means both cooperative learning model NHT type and Talking stick type no more effective than the other one.
\end{abstract}

Keywords: Effectiveness, cooperative learning model NHT type, and Talking Stick type, learning result

\section{INTRODUCTION}

Education is a conscious and planned effort to create active and enjoyable learning and learning process so that students can develop their potential to have spiritual strength, self-control, intelligence, noble character, and skills needed by themselves and society. Education is directed to be able to create superior human resources with all aspects. To achieve this goal, a quality learning system must be created. But the reality in education today is that there are still many problems faced during the learning process. One of the problems of various problems found in the learning process is the lack of enthusiasm for learning students in the learning process in the classroom, making the learning process less well and the learning process is still teacher-oriented.

Based on interviews with mathematics subject teachers at SMP N 3 Sentolo, Kulonprogo Regency, caled that when learning takes place there are some students who pay less attention to teacher's explanations and are busy with their peers, so that easy subject matter will be difficult to learn, resulting in learning outcomes Mathematics students are low and have not met the Minimum completion criteria (MCC) that are determined by the school that is by completing criteria more than or equal to 75 . Mathematics is still seen as a difficult lesson by students, because mathematics is always found in numbers and formulas that are confusing and difficult to understood.

Learning and teaching are different events, but there is a very close relationship with each other. According to Slameto (2010:2), learning is a business process carried out by a person to obtain a change in new behavior as a whole, as a result of his own experience in interaction with his environment. Student learning outcomes can be seen from constant changes in individual behavior. Uno, Hamzah (2007: 213) argues that learning outcomes are behavioral changes that are relatively settled in a person as a result of someone's interaction with their environment. Learning outcomes have several domains or categories and generally refer to aspects of knowledge, attitudes, and skills. One of the things that can trigger students' 
lack of enthusiasm in participating in class is because the teacher has not tried to apply variations of other learning models in presenting the material, so that students are only fixated on the information given by the teacher, namely the teacher explains the material accompanied by questions answer and practice questions then give assignments. An effective learning model is very necessary in the process of learning in the classroom because with the learning model it is expected that students are able to utilize the facilities provided by the teacher so that student learning outcomes can increase.

The effectiveness of learning can be seen from the whole process carried out starting from input - process - output and outcome, so effectiveness does not only prioritize the results to be achieved but there must be a reciprocal relationship between teacher and students so that learning becomes more meaningful. The problem of effectiveness is closely related to the comparison between the level of achievement of goals and plans that have been prepared beforehand. So the better the results obtained, the greater the level of effectiveness used. According to the Indonesian Dictionary in Mulyasa, E (2005: 82) stated that effective means that there is an effect (consequently, the effect, the impression) is effective, can bring results. So effectiveness is the suitability between the person carrying out the task and the intended target. Effectiveness is how an organization succeeds in getting and utilizing resources in an effort to realize operational goals. Many strategies can be done by the teacher to overcome student learning problems, one of them is by applying a cooperative learning model. The application of cooperative learning models is expected to motivate students to be more enthusiastic when the learning process takes place. According to Lie in Mifzal, Abiyu (2015: 33) cooperative learning is a teaching system that provides opportunities for students to work with fellow students in structured tasks. Cooperative learning is a learning strategy with a number of students as members of small groups with different levels of ability. In completing their group assignments, each student group member must work together and help each other to understand the subject matter.

One learning model that can be used as an alternative in mathematics learning is Numbered Heads Together (NHT) and Talking Stick type cooperative learning models. According to Trianto (2009: 82-83) Numbered Head Together (NHT) learning model is a group learning model in which each group member is responsible for his group's assignments, so there is no separation between one student and another in a group. The syntax or steps of NHT type cooperative learning are as follows:

1) Numbering (Numbering)

The teacher divides students into groups of 3-5 people and each group, the member is numbered between 1 and 5 .

2) Asking Questions (Questioning)

The teacher asks a question to the students. Questions can vary. Questions can be very specific and in the form of question sentences.

3) Think Together (Head Together)

Students unite their opinions on the answer to the question and make sure each member of his team knows the answer to the team.

4) Answering

The teacher calls a certain number, then the student whose corresponding number raises his hand and tries to answer the question for the whole class.

While the Talking stick learning model according to Huda, Miftahul (2014: 224-225) is a method of group learning with the help of sticks. Groups that hold sticks must first answer questions from the teacher after they learn the subject matter. In applying this Talking stick method, the teacher divides the class into groups with 4 - 6 heterogeneous members. The syntax of the Talking stick method is as follows:

1) The teacher prepares a stick that is $\pm 20 \mathrm{~cm}$ long.

2) The teacher conveys the subject matter to be studied, then gives the opportunity for the groups to read and study the subject matter.

3) Students discuss discussing the problems contained in the discourse.

4) After students have finished reading the subject matter and studying the contents, the teacher invites students to close the contents of the reading. 
5) The teacher takes the stick and gives it to one of the students, after which the teacher gives a question and the student holding the stick must answer it. And so on until most students get a part to answer each question from the teacher.

6) The teacher gives a conclusion.

7) The teacher conducts an evaluation / assessment

8) The teacher closes the learning.

The purpose of the research was to find out 1) whether or not there is a difference between Mathematics Learning Outcomes Using Cooperative Learning Model NHT Type and Talking Stick VII Grade Students SMP N 3 Sentolo Kulonprogo Regency Even Semester 2015/2016 Academic Year. 2) This is more effective between the use of the Cooperative Learning Model NHT Type and Talking Stick VII Grade Students in SMP N 3 Sentolo in Kulonprogo Regency in Even Semester of 2015/2016 Academic Year.

\section{METHODS}

This type of research is experimental research. Experimental research is a study conducted by learning something that is held, in other words in experimental research there is treatment from researchers and can be measured the impact. The population in this study were seventh grade students of Sentolo Cale Middle School 3 Kulonprogo Regency even semester 2015/2016 academic year consisting of 6 classes namely class VII A, VII B, VII C, VII D, VII E, VII F. sampling was done with random sampling technique, where sampling from the population is done randomly by the lottery system. The results of the draw were obtained by two classes as the experimental class, namely class VII A as the experimental class I who received treatment with the cooperative learning model type NHT and class VII $\mathrm{C}$ as the experimental class II which received treatment with the cooperative learning type Talking stick, while for Instrument test class was obtained in class VII B.

Data collection techniques used are documentation techniques and test techniques. Documentation techniques are used to determine students 'initial mathematical abilities before an experiment is conducted, while test techniques are used to evaluate students' mathematics learning outcomes. The test of the research instrument used was the content validity test, item validity test, different power test, and reliability test. Then for the analysis prerequisite test used is the normality test and homogeneity test. Data analysis for hypothesis testing using the two-party hypothesis test and one party hypothesis test.

\section{RESULTS AND DISCUSSION}

\section{Prerequisite Test for Analysis}

\section{a. Normality Test}

The details of the calculation of the normality test can be seen in Table 1.

Table 1. Details of the Calculation Results for the Normality Test

\begin{tabular}{|l|c|c|l|}
\hline Treatment & $\chi_{\text {cal }}^{2}$ & $\chi_{\text {table }}^{2}$ & df \\
\hline $\begin{array}{l}\text { Experiment } \\
\text { class I }\end{array}$ & 0,4985 & 5,9915 & 2 \\
\hline $\begin{array}{l}\text { Experiment } \\
\text { class II }\end{array}$ & 0,8486 & 3,8415 & 1 \\
\hline
\end{tabular}

From the table above with a significant level of $5 \%$ obtained $\chi_{c a l}^{2}<\chi_{\text {table }}^{2}$, this means that each experimental class is normally distributed.

\section{b. Homogeneity test}

The details of the calculation of the homogeneity test can be seen in Table 2 . 
Table 2. Details of Homogeneity Test Calculation Results

\begin{tabular}{|c|c|c|c|}
\hline$\chi_{\text {cal }}^{2}$ & $\chi_{\text {table }}^{2}$ & significant level & $\mathrm{df}$ \\
\hline 1,4609 & 3,8415 & $5 \%$ & 1 \\
\hline
\end{tabular}

From the table above it can be seen that $\chi_{\text {cal }}^{2}<\chi_{\text {table }}^{2}$, this means that the value of student mathematics learning outcomes is homogeneous.

\section{Test the Hypothesis}

\section{a. Test of Two-party Hypothesis}

The details of the results of homogeneity test calculations can be seen in Table 3 .

Table 3. Details of the Test Results of the Two Parties Hypothesis

\begin{tabular}{|c|c|c|c|}
\hline$t_{\text {cal }}$ & $t_{\text {table }}$ & significant level & $\mathrm{df}$ \\
\hline$-1,4079$ & 2,0045 & $5 \%$ & 56 \\
\hline
\end{tabular}

From the table above it can be seen that $t_{c a l}<t_{\text {table }}$, this means that there is no difference in mathematics learning outcomes using the NHT cooperative learning model and Talking Stick.

b. Test of One Party Hypothesis

The details of the results of homogeneity test calculations can be seen in Table 4 .

Table 4. Details of One-Party Hypothesis Test Results

\begin{tabular}{|c|c|c|c|}
\hline$t_{c a l}$ & $t_{\text {table }}$ & significant level & df \\
\hline$-1,4079$ & 1,6733 & $5 \%$ & 56 \\
\hline
\end{tabular}

From the table above it can be seen that $t_{c a l}<t_{\text {table }}$, this means that there is no more effective type of NHT cooperative learning model and Talking Stick with each other.

\section{CONCLUSION}

Based on the results of research and discussion, it can be concluded that:

1. There is no difference in the mathematics learning outcomes of students who use the NHT type cooperative learning model and the Talking stick Class VII Students in SMP N 3 Sentolo Kulonprogo Regency even in the academic year 2015/2016.

2. The NHT cooperative learning model and Talking Stick are not more effective with each other.

\section{REFERENCES}

Huda, Miftahul. 2014. Model-Model Pengajaran dan Pembelajaran (Isu-Isu Metodis dan Paradigmatis). Yogyakarta: Pustaka Pelajar.

Mifzal, Abiyu. 2015. Strategi Pembelajaran untuk Anak Kurang Berprestasi. Jogjakarta: Javalitera.

Mulyasa, E. 2005. Manajemen Berbasis Sekolah. Bandung: PT Remaja Rosdakarya.

Slameto. 2010. Belajar dan Faktor-faktor yang Mempengaruhinya. Jakarta: Rineka Cipta.

Trianto. 2009. Mendesain Model Pembelajaran Inovatif-Progresif: Konsep, Landasan, dan Implementasinya pada Kurikulum Tingkat Satuan Pendidikan (KTSP). Jakarta: Kencana Prenada Media Group.

Uno, B Hamzah, 2007. Model Pembelajaran Menciptakan Proses Belajar Mengajar Yang Kreatif dan Efektif. Jakarta : Bumi Aksara. 